\title{
Omnivorous Carp (Carassius gibelio) Increase Eutrophication in Part by Preventing Development of Large-Bodied Zooplankton and Submerged Macrophytes
}

\author{
Vladimir Razlutskij ${ }^{1, *}$, Xueying Mei ${ }^{2,+}$, Natallia Maisak ${ }^{1}$, Elena Sysova ${ }^{1}$, Dzmitry Lukashanets ${ }^{1}$, \\ Andrei Makaranka ${ }^{1}$, Erik Jeppesen ${ }^{3,4,5,6}{ }^{-}$and Xiufeng Zhang ${ }^{7}$
}

1 State Scientific and Production Amalgamation Scientific-Practical Center of the National Academy of Sciences of Belarus for Biological Resources, 220072 Minsk, Belarus; vok-n@mail.ru (N.M.); sysovaelena@mail.ru (E.S.); lukashanetzdm@rambler.ru (D.L.); amakarenko198989@mail.ru (A.M.)

2 College of Resources and Environment, Anhui Agricultural University, Hefei 230036, China; qxxmxy@163.com

3 Department of Bioscience and WATEC, Aarhus University, 8600 Silkeborg, Denmark; ej@bios.au.dk

4 Sino-Danish Centre for Education and Research (SDC), Beijing 100049, China

5 Limnology Laboratory, Department of Biological Sciences and Centre for Ecosystem Research and Implementation, Middle East Technical University, Ankara 06800, Turkey

6 Institute of Marine Sciences, Middle East Technical University, Erdemli, Mersin 33731, Turkey

7 Department of Ecology and Institute of Hydrobiology, Jinan University, Guangzhou 510632, China; wetlandxfz@163.com

check for

updates

Citation: Razlutskij, V.; Mei, X.; Maisak, N.; Sysova, E.; Lukashanets, D.; Makaranka, A.; Jeppesen, E.; Zhang, X. Omnivorous Carp (Carassius gibelio) Increase

Eutrophication in Part by Preventing Development of Large-Bodied Zooplankton and Submerged Macrophytes. Water 2021, 13, 1497. https://doi.org/10.3390/w13111497

Academic Editor: José Maria Santos

Received: 28 April 2021

Accepted: 22 May 2021

Published: 27 May 2021

Publisher's Note: MDPI stays neutral with regard to jurisdictional claims in published maps and institutional affiliations.

Copyright: (c) 2021 by the authors. Licensee MDPI, Basel, Switzerland. This article is an open access article distributed under the terms and conditions of the Creative Commons Attribution (CC BY) license (https:// creativecommons.org/licenses/by/ $4.0 /)$.
* Correspondence: vladimirrazl@gmail.com

+ The author contributed equally to this work.

\begin{abstract}
Fish, being an important consumer in aquatic ecosystems, plays a significant role by affecting the key processes of aquatic ecosystems. Omnivorous fish consume a variety of food both from pelagic and benthic habitats and may directly or indirectly affect the plankton community as well as the lake trophic state. We conducted a 72-day outdoor experiment in mesocosms with and without Prussian carp (Carassius auratus) to evaluate the effect of this often-stocked omnivorous fish on the plankton community and water quality. We found that the presence of fish increased the biomass of planktonic algae, total and inorganic suspended solids, leading to decreased light intensity in the water and a lower biomass of benthic algae. Fish also prevented development of submerged macrophytes and the establishment of large-bodied zooplankton. However, the fish did not increase nitrogen concentrations and even was lowered total phosphorus levels, in part due to nutrient storage in the fish. We conclude that stocking of Prussian carp should be avoided, or removed where stocked and abundant, to obtain good ecological quality of shallow lakes, characterized by clear water and high abundance of macrophytes.
\end{abstract}

Keywords: Prussian carp; nutrients; phytoplankton; benthic algae; water quality

\section{Introduction}

Eutrophication due to excess nutrient inputs, leading to extensive growth of planktonic algae, is one of the most common water quality problems in shallow lakes worldwide [1-3]. When abundant, planktonic algae reduce water transparency and prevent penetration of light into deeper layers, which, in turn, may reduce the growth of benthic primary producers such as benthic algae [4-6]. A decrease in benthic primary production may result in higher growth of planktonic algae through reduced competition for nutrients and enhanced internal nutrient loading from the sediment [7].

Fish, an important consumer in aquatic ecosystem, plays a significant role in lakes by affecting key processes and may even trigger catastrophic changes [8]. However, the different functional groups of fish affect the ecosystems in different ways [9-11]. Filtering fish such as silver carp (Hypophthalmichthys molitrix) filter plankton and particles in the water 
column and is supposed to have a positive effect on water quality [12], although this view is controversial as they also consume the zooplankton, thereby reducing the grazing on planktonic algae [13]. Other fish, such as common carp (Cyprinus carpio) consume a variety of food items from both the pelagic and benthic habitats, and they may have profound effects on the aquatic ecosystems $[14,15]$. They affect nutrient recycling and then primary productivity in aquatic ecosystems, either directly or indirectly [16,17]: they may enhance the growth of planktonic algae through bottom-up effects by translocating nutrients from sediments to the water column [18-20] as well as by disturbance and through excretion [8,21]. In addition, omnivorous fish can predate on phytoplankton-consuming zooplankton, thereby reducing their abundance and changing their community structure [22-24]. They may, however, also increase turbidity through resuspension of bottom sediments when feeding [25-27], potentially with negative effect on primary producers. Omni-benthivorous fish may also affect the plants by uprooting or by consuming them. By feeding sediment, they may also reduce the amount of overwintering organs (tubers, oocytes, etc.) $[8,28]$ and the amount of resting eggs of cladocerans stored in the sediment [29], thereby preventing development of plants and large-bodied cladocerans, which potentially may lead to higher planktonic algae growth. Some studies though found no net effects of omnivorous fish on nutrients and biomass of planktonic algae (chlorophyll $a(\mathrm{chl} a)$ ) [30]. In addition, the impact of fish on nutrient concentrations and water turbidity varied with season and latitude in a Pan-European mesocosm experiment [31], emphasizing that more work is needed to fully elucidate the effects of omnivorous fish on plankton communities and water quality.

Omni-benthivorous Prussian carp (Carassius auratus gibelio) consume a wide range of food items [32]. Its population grows rapidly due to precocious maturity and reproduction through gynogenesis, it can produce several times per year and has a high fecundity [33-35]. It can tolerate polluted water and other stressful conditions $[33,35,36]$. Prussian carp is now widely distributed in Europe from the Iberian Peninsula to the Black Sea region, with the exception of the northern regions (Ireland, Scotland and part of Scandinavia) [37,38], and it has spread to all types of waterbodies of the Dnieper, Pripyat, Zapadnaya Dvina and Neman river basins [39].

Prussian carp is invasive species in Belarus [40] and began to spread after acclimatisation in 1948. From the Amur basin, it has been introduced into waterbodies of different types in the north of Belarus and fish farms in the south of the country. In 1954, the species began to breed in many fish ponds of the republic, thereby introducing to natural waterbodies. In 2006, the Prussian carp was recognised as the most effective species for fish production and its massive introduction into natural aquatic environments was therefore continued. Currently, Prussian carp bred in most of the fish farms in Belarus. In addition, its potential for further expansion is strong, entailing a potential profound impact on the ecological state of aquatic ecosystems.

To evaluate the impact of the Prussian carp on the plankton community and water quality, we conducted an outdoor mesocosm experiment with and without fish. We hypothesised that the presence of Prussian carp would change the plankton community, enhance planktonic algae growth and prevent the development of submerged macrophytes and large-bodied zooplankton, thereby enhancing the eutrophication.

\section{Materials and Methods}

\subsection{Experimental Mesocosm Setup}

The mesocosm experiment was carried out in 10 circular plastic tanks (upper diameter $=60 \mathrm{~cm}$, bottom diameter $=50 \mathrm{~cm}$, height $=105 \mathrm{~cm}$ ) containing sediment and water. The tanks were semi-transparent and light beige. Sediment was obtained from Lake Obsterno, a mesotrophic natural shallow lake $\left(9.9 \mathrm{~km}^{2}\right.$, mean depth $\left.5.0 \mathrm{~m}\right)$ located in the north-west of Belarus ( $55^{\circ} 62^{\prime} 6118^{\prime \prime} \mathrm{N} ; 27^{\circ} 36^{\prime} 0255^{\prime \prime} \mathrm{E}$ ). To remove coarse debris and other major obstacles, the sediment was air dried and sieved through a stainless steel sieve (mesh size $0.5 \mathrm{~mm}$ ). A layer of $\sim 10 \mathrm{~cm}$ homogenised sediment was added to each tank. Then the tanks were filled with the lake water (total phosphorus $0.167 \mathrm{mg} / \mathrm{L}$ ) filtered through a plankton net (mesh 
size $=0.07 \mathrm{~mm}$ ). The mesocosms were then exposed to natural sunlight and equilibrated for two weeks.

After acclimatisation, two petri dishes (diameter $9 \mathrm{~cm}$ ) filled with homogenized sediment were inserted into the bed of each tank to allow surface colonisation by benthic algae [14] for determination of algal biomass and composition. One C. gibelio with a length of $14 \mathrm{~cm}$ was added to each of the five fish treatment replicates. One week after acclimatisation, nitrogen $(\mathrm{N}, 0.83 \mathrm{mg} / \mathrm{L})$ in the form of $\mathrm{KNO}_{3}$ and phosphorus $(\mathrm{P}, 0.065 \mathrm{mg} / \mathrm{L})$ as $\mathrm{NaH}_{2} \mathrm{PO}_{4}$ were added to mimic the external loading. During the first week, one of the added fish was found dead and substituted. To be sure that all fish treatments had fish, one more $C$. gibelio individual was stocked to each tank the following week. Another five mesocosms without fish served as controls. The experiment ran from 6 June to 16 August 2018 at natural sunlight and temperature.

\subsection{Sampling and Analysis}

Every two weeks, water samples $(1 \mathrm{~L})$ were collected $30 \mathrm{~cm}$ below the surface in each mesocosm for determination of chlorophyll $a$ of planktonic algae, total suspended solids (TSS), inorganic suspended solids (ISS), ammonium (AN), nitrate nitrogen (NN) and total phosphorus (TP) concentrations. AN and $\mathrm{NN}$ were determined using a multiparametric fluorimeter (Hanna C 205, HI-8300). TP was determined by plasma mass spectrometry (ISO 17294-2:2016) in the water and particulate P (PP) in the seston (residual matter from water filtered through GF/C filters (with a pore diameter of $1 \mu$ ). TSS was calculated by weighing GF/C filters (with residual matter from filtered water) dried at $105^{\circ} \mathrm{C}$ for $24 \mathrm{~h}$ and then combusted at $550{ }^{\circ} \mathrm{C}$ for $2 \mathrm{~h}$ to calculate ISS.

The petri dish with benthic algae was removed every two weeks from each mesocosm after planktonic algae sampling and replaced by another petri dish. Benthic algae were collected by scraping the surface of the sediment into the petri dish using a razor blade [41]. $\mathrm{Chl} a$ of benthic and planktonic algae was spectrophotometrically determined after ethanol extraction of residual matter on GF/C grade filters at room temperature [42]. At the end of experiment, the algae from the second petri dishes were used to identify species composition and calculate the biovolume percentages of different algae groups.

Since the transparency of the water differed between the controls and the fish treatment, light intensity was measured at two-week sampling intervals between $11 \mathrm{a} . \mathrm{m}$. and noon using a lux meter $1.0 \mathrm{~m}$ below the water surface in the control mesocosms and at $0.5 \mathrm{~m}$ in the fish mesocosms before water sampling. At the end of the experiment, $50 \mathrm{~L}$ water from each mesocosm was taken with Ruttner bathometer ( $V=3 \mathrm{~L}$ ), from surface to bottom and filtered (mesh size $37 \mu \mathrm{m}$ ) for zooplankton samples. Zooplankton taxa were identified to species or to the lowest taxonomic level $[43,44]$.

Charophytes appeared in the control mesocosms during the experiment. To assess their amount, they were collected from each mesocosms at the end of the experiment and total biomass weighed after air-drying for half an hour.

By feeding sediment omni-benthivorous fish may affect the amount of resting eggs of cladocerans stored in the sediment. To check this, we measured the amounts of cladoceran ephippias in $5 \mathrm{~cm}^{3}$ top layers of sediments from the controls and fish mesocosms. The sediments were taking by petri dish after the collection of all other samples at the end of experiment.

\subsection{Statistical Analysis}

One-way ANOVA with Tukey's HSD test $(p<0.05)$ was used to compare the means of all measured parameters between the control and experimental treatments for each separate date. Data were log-transformed, if necessary, to help meet the assumptions of normality of residuals and then tested following Levene's criterion. All statistics were done using the software SPSS 19.0 (SPSS Inc., Chicago, IL, USA). 


\section{Results}

\section{1. $N$ and $P$}

The TP concentration was lower in the fish treatment than in the controls, especially after two weeks but also at the end of the experiment (one-way-ANOVA, $p<0.01$, Figure 1a), whereas no statistical differences were observed for ammonium and nitrate nitrogen (Figure $1 b, c)$. Particulate $P(P P)$ did not differ between the control and the fish treatments (Figure 2c).
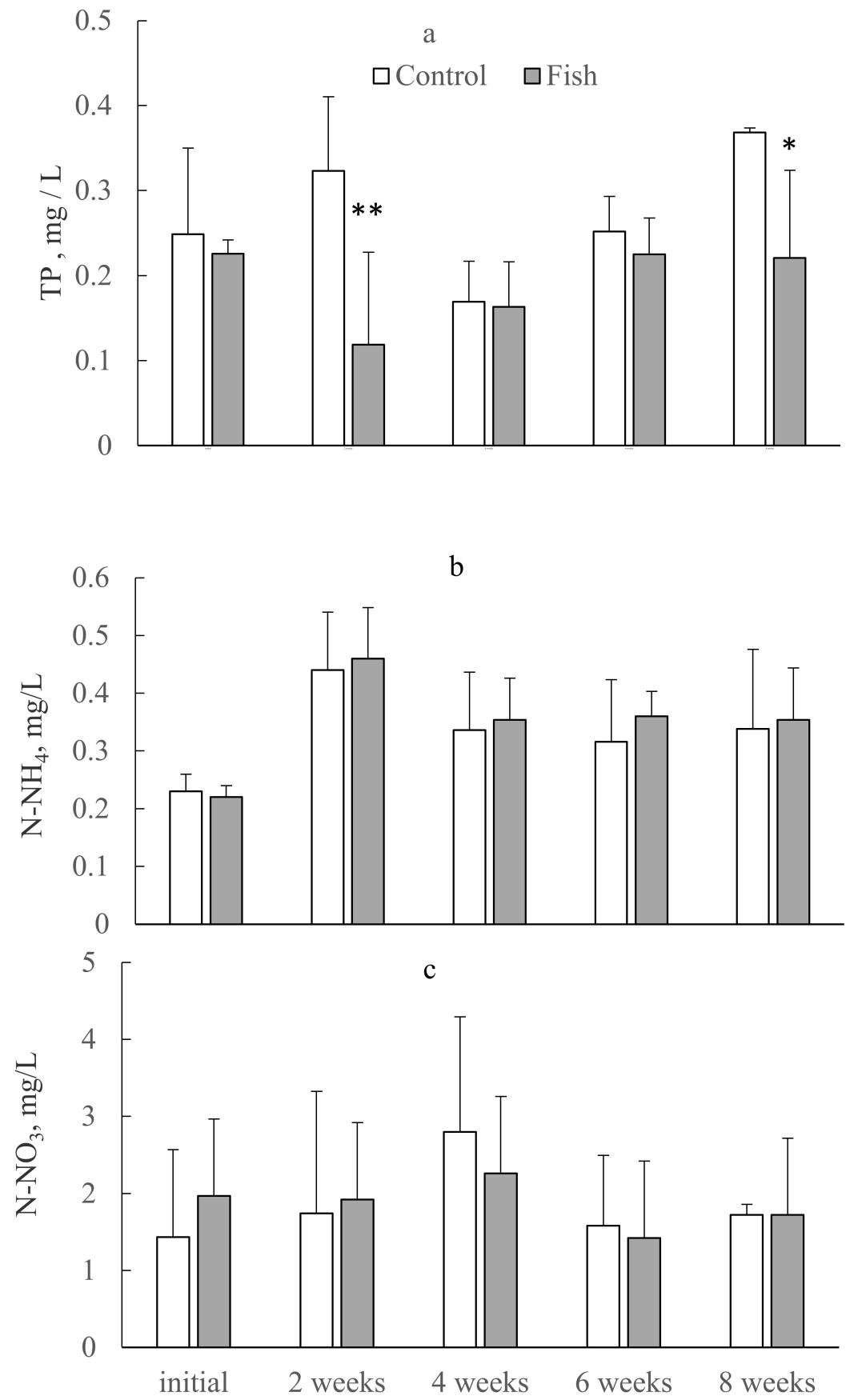

Figure 1. Concentrations of total phosphorus (a), ammonium (b) and nitrate (c) in the water in the control and fish treatments over time. Asterisks indicate significant differences (one-way-ANOVA, $\left.{ }^{*} p<0.05,{ }^{* *} p<0.01\right)$. Bars indicate $\pm 1 \mathrm{SD}$. 

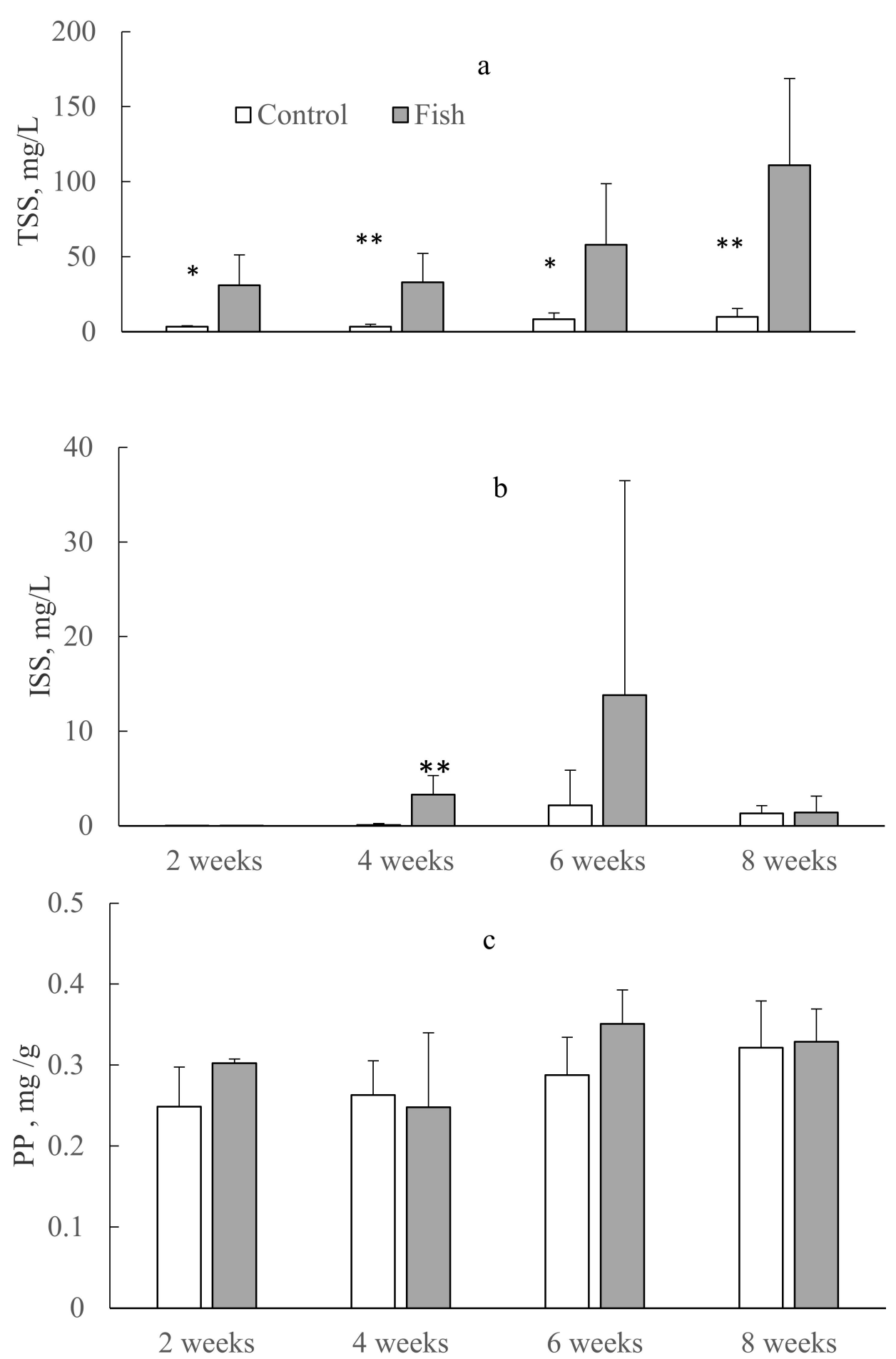

Figure 2. TSS (a), ISS (b) and PP (c) concentrations (from $1 \mu$ GF filters) in the control and fish treatments over time. Asterisks indicate significant differences (one-way-ANOVA, ${ }^{*} p<0.05,{ }^{* *} p<0.01$ ). Bars indicate \pm 1 SD.

\subsection{TSS, ISS and Light Intensity}

TSS (Figure 2a) was higher in the fish treatment than in the controls (one-way-ANOVA, $p<0.001$ ) and the difference was statistically significant on all sampling occasion (oneway-ANOVA, $p<0.01)$. ISS was also higher in the fish treatment than in the controls (one-way-ANOVA, $p<0.017$ ), and the difference was statistically significant after 4 weeks (Figure 2b). Light intensity at the sediment surface was lower (one-way ANOVA, $p<0.001$ ) 
in the fish treatments $(1000 \pm 300$ lux $)$ than in the controls $(10,100 \pm 100$ lux $)$ at the end of the experiment.

\subsection{Biomass (Chl a Concentrations) and Compositions of Planktonic and Benthic Algae}

The biomass of planktonic algae (expressed as chl $a$ ) did not differ between the treatments in the beginning of experiment (one-way ANOVA, $p=0.478$ ). Thereafter it was higher in the fish treatments than in the controls (one-way ANOVA, $p<0.001$ ) on each sampling occasion (Figure 3a). In contrast, the biomass of benthic algae (chlorophyll $a$ ) was lower in the fish treatments than in the controls (one-way ANOVA, $p<0.01$ ).
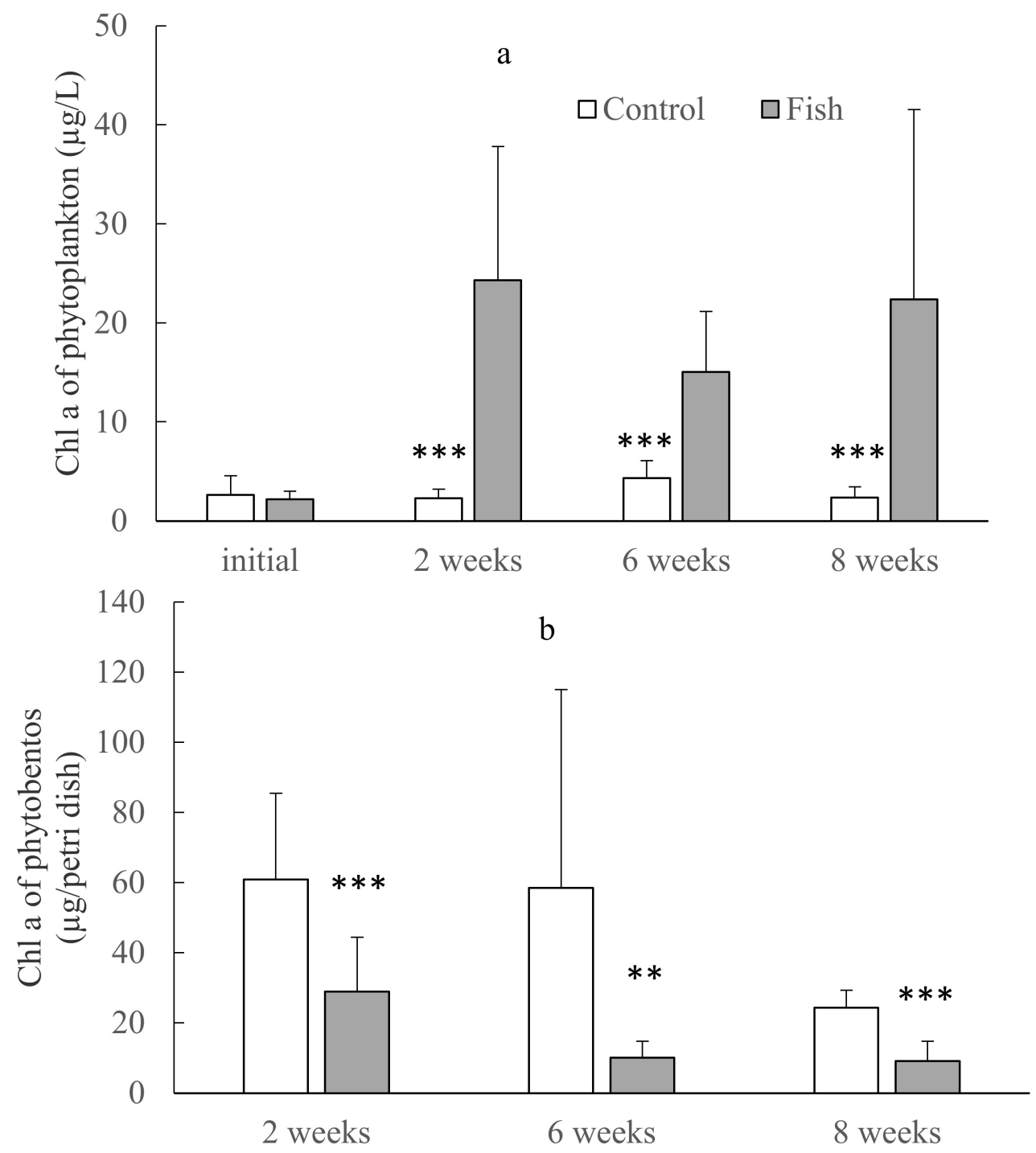

Figure 3. Planktonic algae (a) and benthic (b) algal biomass ( $\mathrm{chl} a)$ in the control and fish treatments over time. Asterisks indicate significant differences $\left.{ }^{* *} p<0.01,{ }^{* * *} p<0.001\right)$. Bars indicate $\pm 1 \mathrm{SD}$.

The planktonic algae community were dominated by Chlorophyta, mostly Chlorococcum infusionum, Scenedesmus ecornis and S. quadricauda in both the controls and the fish treatments (Figure 4a). Pediastrum duplex, Golenkiniopsis parvula and Cosmarium humile were also abundant in the fish treatments. Cryptomonas ovata was quite abundant in the controls, but absent in the fish treatments. 

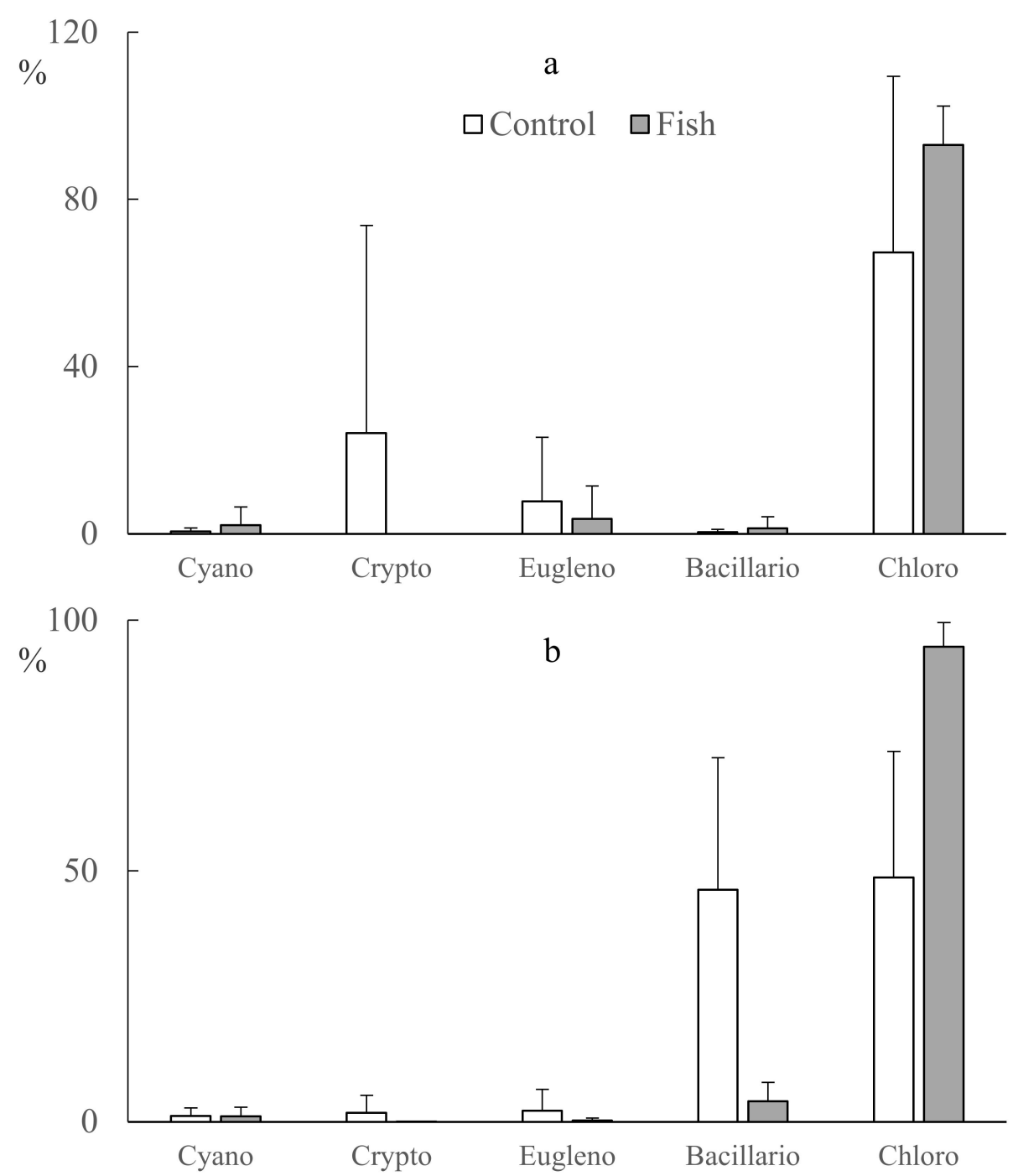

Figure 4. The percentage of total biomass (biovolumes) of different groups of planktonic (a) and benthic (b) algae in the control and fish treatments at the end of the experiment. Bars indicate \pm 1 SD. Cyano-Cyanophyta, Crypto-Cryptophyta, Eugleno-Euglenophyta, Bacillario-Bacillariophyta, Chloro-Chlorophyta.

The benthic algae were dominated by Bacillariophyta and Chlorophyta in the controls and contributed equally to the total biovolum. Chlorophyta clearly dominated in the fish treatments (Figure $4 \mathrm{~b}$ ). In both treatments, Bacillariophyta mainly consisted of Cymbella silesiaca, Fragilaria construens and Navicula scutelloides. Chlopophyta were dominated by Tetraedron minimum, Scenedesmus quadricauda and Chlorococcum infusionum.

\subsection{Submerged Charophytes}

Charophytes rooted (Chara sp.) and filamentous algae (Spirulina sp. and Mougeotia sp.) were abundant in the controls ( $1.5 \pm 0.5 \mathrm{~kg}$ per mesocosm) at the end of the experiment, but absent in the fish treatments.

\subsection{Density and Composition of Zooplankton}

At the beginning of the experiments, zooplankton was not recorded in any of the mesocosms (dried sediment used). At the end of the experiment, the densities of zooplankton were $0.39 \pm 0.39 \mathrm{ind} . / \mathrm{L}$ in the fish treatments and $166.5 \pm 155.3 \mathrm{ind} . / \mathrm{L}$ in the controls. In the controls, the zooplankton was dominated by Chydorus sphaericus (up to 208.3 ind./L on average), Daphnia longispina (up to 48.4 ind./L) and Scapholeberis mucronata 
(up to 53.9 ind./L). In the fish treatments, although cladocerans (Chydorus sphaericus, Daphnia cucullata and Scapholeberis mucronata) and copepods (nauplii, cyclops copepodites and Eudiaptomus graciloides) were recorded in low densities (about 0.01 ind./L), Rotifera such as Lecane closterocerca (up to 0.5 ind./L), Keratella cochlearis (up to 0.4 ind./L) and Bdelloidea sp. (up to 0.4 ind./L) were dominant. The densities of zooplankton except Rotifera, were lower in fish treatments than in the controls (one-way ANOVA, $p<0.05$, Table 1).

Table 1. The densities (ind./L \pm SD) of different zooplankton groups in the control and fish treatments at the end of the experiment.

\begin{tabular}{ccc}
\hline Zooplankton Groups & Control & Fish \\
\hline Nauplies & $6.7 \pm 9.2$ & $0.06 \pm 0.07^{* *}$ \\
Copepodites & $45.2 \pm 37.0$ & $1.3 \pm 1.5^{* *}$ \\
Adalt copepods & $2.0 \pm 2.1$ & $0.05 \pm 0.09^{* *}$ \\
Cladocera & $111.3 \pm 113.3$ & $0.1 \pm 0.1^{* *}$ \\
Rotifera & $0.4 \pm 0.9$ & $3.0 \pm 2.8^{*}$ \\
\hline
\end{tabular}

One-way-ANOVA, ${ }^{*} p<0.05,{ }^{* *} p<0.01$.

At the end of the experiment the number (mean \pm SD pieces per $5 \mathrm{~cm}^{3}$ ) of resting eggs was higher in the controls $(2.40 \pm 0.89)$ than in the fish treatments $(0.75 \pm 0.96)$ (one-way ANOVA, $p=0.032)$. The morphology of ephippia matched D. longispina $[45,46]$.

\section{Discussion}

The presence of fish increased the planktonic algal biomass, TSS and ISS and decreased the light intensity. Other investigations have shown that Prussian carp can increase turbidity, decrease benthic algae biomass and enhance the release of nutrients from the sediment to the water, becoming available for and promoting planktonic algae growth $[26,28]$. Our results are, in part, consistent with these findings. However, we did not find an increase in nutrient concentrations in the water in the fish treatments and TP was even lower here than in the controls. Fish can act as sources or sinks of nutrients [47]. The fish increased in weight (5.53 $\pm 2.97 \mathrm{~g}$, on average) during the experiment. Assuming a 10\% dry/wet biomass, a $\mathrm{N}$ content of $9.0 \%$ and a P content of $2.35 \%$ of the fish dry biomass [48], $49.7 \pm 26.7 \mathrm{mg} \mathrm{N}$ and $13.0 \pm 7.0 \mathrm{mg} P$ were accumulated in the biomass during the experimental period. In comparison, $25 \mathrm{mg}$ of $\mathrm{P}$ and $600 \mathrm{mg}$ and $\mathrm{N}$ were added to each mesocosm, respectively. Thus, the fish had accumulated an essential part of the added P, but not N. In addition, the sediment used in our experiment probably had low content of nutrients and might have functioned as a sink. Unfortunately, the nutrient content of the sediment was not measured. Another possibility is that the nutrients were consumed by periphyton on the walls of the mesocosms [49-51], that likely had higher biomasses than in the turbid mesocosms with fish no data available though.

The biomass of planktonic algae increased markedly in the presence of fish (Figure 3a), with a high percentage of green algae, indicating that the fish stimulated algal growth (Figure 4a). In addition, the fish also changed the planktonic algae community composition. Cryptophyta were recorded in the control mesocosms but not in those with fish. These groups of algae are poorly adapted to low light conditions [52].

Charophytes developed in the control mesocosms with clear-water conditions. These macrophytes are abundant in Lake Obsterno where the sediments used in our experiment were collected. Submerged vegetation can positively affect water clarity in many ways, including competition for nutrients $[53,54]$ and suppression of microalgae by allelopathic material production $[55,56]$. Therefore, charophytes likely contributed to the low biomass of planktonic algae in the controls. Fish decreased the light intensity, i.e., they decreased the Secchi-disk transparency (less than $30 \mathrm{~cm}$ ). A long-term dataset of Lake Veluwe showed the disappearance of charophytes during the eutrophication when transparency was $<40 \mathrm{~cm}$ [57]. Results from an enclosure experiment in shallow Lake Rotoroa, New Zeeland also showed a negative effect of fish on the abundance of charophytes [58]. The 
authors suggested that fish impacted plants via uprooting, shading by deposited sediment, mechanical damage, grazing, or through combination of these mechanisms. In addition, decline of light and negative impact of fish were assumed to be the most probable reason for the decline of charophytes in several lakes in southern Sweden during its eutrophication [59]. Thus, Prussian carp can create conditions that prevent the development of submerged macrophytes, and perhaps also by consuming seeds in the sediment.

We found that the light intensity in the bottom water declined to about 1000 lux in the fish treatment as compared with 10,100 lux in the controls, so low light likely contributed importantly to the lower benthic algae biomass in the treatments with fish. Benthic algae may account for the majority of primary productivity in clear shallow lakes $[5,60]$ and reduce the release of Sediment $P$ via direct uptake $[7,61]$ by increasing the oxygen concentration in the sediments during the photosynthesis process, thereby inhibit $\mathrm{P}$ nutrient release by binding $\mathrm{P}$ with oxidised Fe- and Mn-compounds in the bottom layer [7,62]. Thus, omnivorous Prussian carp can enhance the competitive ability of plankton algae and trigger a shift in dominance from benthic to planktonic algae, thereby enhancing eutrophication. Consumption of benthic algae by the fish may have contributed as well.

Prussian carp also changed the composition of the zooplankton community. At the end of the experiment, only small zooplankton was present in the fish mesocosms, while large-sized zooplankton, such as Daphnia longispina and Scapholeberis mucronata were abundant in the control. In addition, fish also reduced the total density of zooplankton. Our results concur with the well-known fact that fish selectively consume large-bodied zooplankters [63]. Zooplankton grazing can be the key factor affecting the planktonic algae community and their biomasses. In addition, consumption of resting eggs when feeding in the sediment could be another reason for the reduction of large-size zooplankton. Mellors [64] found large number of resting eggs of Daphnia in the digestive tract of fish. Unfortunately, we did not analyze the content of fish guts, but we did find about three times more cladoceran ephippia in the sediments from control mesocosms than in the fish treatments by the end of the experiment. Besides, the obvious predation on living cladocerans, the poor development of large-size zooplankton in the fish treatments may thus, in part, be attributed to consumption of resting eggs by the fish, as the cladocerans did not produce resting eggs during our experiment, so the lower ephippia density must reflect consumption.

\section{Conclusions}

We found that omnivorous Prussian carp not only increased TSS and ISS, enhanced the growth of planktonic algae, decreased light conditions, reduced benthic algae growth, but also reduced the zooplankton biomass, especially large-sized species, and prevented submerged macrophyte development, thereby enhancing eutrophication.

Author Contributions: Conceptualization, V.R., X.M., X.Z.; methodology, V.R., X.M., X.Z.; software, V.R.; validation, V.R., X.M. and X.Z.; formal analysis, V.R., X.M., X.Z., E.J.; investigation, V.R., N.M., E.S., A.M., D.L.; resources, V.R.; data curation, X.Z., E.J.; writing-original draft preparation, V.R.; writing-review and editing, X.M., X.Z., E.J.; visualization, V.R.; project administration, V.R., X.M.; funding acquisition, V.R., X.M., E.J. All authors have read and agreed to the published version of the manuscript.

Funding: This work was supported by the Belorussian Republican Foundation for Basic Research (B20KI011) with additional support from the National Natural Science Foundation of China (No. 41771100; 41811530056). E. Jeppesen was supported by the TÜBITAK program BIDEB 2232 (project 118C250), the EU-H2020, INFRAIA project AQUACOSM (Project no 731063), and AQUACOSM-Plus (no 871081).

Institutional Review Board Statement: The study was conducted according to the guidelines of the Declaration of Helsinki, and approved by the Institutional Review Board of State Scientific and Production Amalgamation Scientific-Practical Center of the National Academy of Sciences of Belarus for Biological Resources (protocol N. 51 dated 20 March 2021).

Informed Consent Statement: Not applicable. 
Data Availability Statement: The data presented in this study is available in the current manuscript. Raw data is available on request from the corresponding author.

Acknowledgments: We thank Anne Mette Poulsen, Aarhus University, for the English edition.

Conflicts of Interest: The authors declare no conflict of interest.

\section{References}

1. Schindler, D.W.; Hecky, R.E.; Findlay, D.L.; Stainton, M.P.; Parker, B.R.; Paterson, M.J.; Beaty, K.G.; Lyng, M.; Kasian, S.E.M. Eutrophication of lakes cannot be controlled by reducing nitrogen input: Results of a 37-year whole-ecosystem experiment. Proc. Natl. Acad. Sci. USA 2008, 105, 11254-11258. [CrossRef] [PubMed]

2. Smith, V.H.; Schindler, D.W. Eutrophication science: Where do we go from here? Trends Ecol. Evol. 2009, 24, 201-207. [CrossRef] [PubMed]

3. Schindler, D.W. Lakes as sentinels and integrators for the effects of climate change on watersheds, airsheds, and landscapes. Limnol. Oceanogr. 2009, 54, 2349-2358. [CrossRef]

4. Hansson, L.A. Effects of competitive interactions on the biomass development of planktonic and periphytic algae in lakes. Limnol. Oceanogr. 1998, 33, 121-128. [CrossRef]

5. Vadeboncoeur, Y.; Jeppesen, E.; Zanden, M.J.V.; Schierup, H.H.; Christoffersen, K.; Lodge, D.M. From Greenland to green lakes: Cultural eutrophication and the loss of benthic pathways in lakes. Limnol. Oceanogr. 2003, 48, 1408-1418. [CrossRef]

6. Cantonati, M.; Lowe, R.L. Lake benthic algae: Toward an understanding of their ecology. Freshw. Sci. 2014, 33, 475-486. [CrossRef]

7. Zhang, X.; Liu, Z.; Gulati, R.D.; Jeppesen, E. The effect of benthic algae on phosphorus exchange between sediment and overlying water in shallow lakes: A microcosm study using 32P as a tracer. Hydrobiologia 2013, 710, 109-116. [CrossRef]

8. Zambrano, L.; Scheffer, M.; Martínez-Ramos, M. Catastrophic response of lakes to benthivorous fish introduction. Oikos 2001, 94, 344-350. [CrossRef]

9. Andersson, G.; Berggren, H.; Cronberg, G.; Gelin, C. Effects of planktivorous and benthivorous fish on organisms and water chemistry in eutrophic lakes. Hydrobiologia 1978, 59, 9-15. [CrossRef]

10. Eggers, D.M.; Bartoo, N.W.; Rickard, N.A.; Nelson, R.E.; Wissmar, R.C.; Burgner, R.L.; Devol, A.H. The Lake Washington ecosystem: The perspective from the fish community production and forage base. J. Fish. Res. Board Can. 1978, 35, 1553-1571. [CrossRef]

11. Jeppesen, E.; Jensen, J.P.; Jensen, C.; Faafeng, B.; Hessen, D.O.; Søndergaard, M.; Lauridsen, T.; Brettum, P.; Christoffersen, K. The impact of nutrient state and lake depth on top-down control in the pelagic zone of lakes: A study of 466 lakes from the temperate zone to the arctic. Ecosystems 2003, 6, 313-325. [CrossRef]

12. Attayde, J.L.; van Nes, E.H.; Araujo, A.I.; Corso, G.; Scheffer, M. Omnivory by planktivores stabilizes plankton dynamics, but may either promote or reduce algal biomass. Ecosystems 2010, 13, 410-420. [CrossRef]

13. Mao, Z.; Gu, X.; Cao, Y.; Zhang, M.; Zeng, Q.; Chen, H.; Shen, R.; Jeppesen, E. The role of top-down and bottom-up control for phytoplankton in a subtropical shallow eutrophic lake: Evidence based on long-term monitoring and modelling. Ecosystems 2020, 23, 1449-1463. [CrossRef]

14. Zhang, X.F.; Liu, Z.W.; Jeppesen, E.; Taylor, W.D.; Rudstam, L.G. Effects of benthic-feeding common carp and filterfeeding silver carp on benthic-pelagic coupling: Implications for shallow lake management. Ecol. Eng. 2016, 88, 256-264. [CrossRef]

15. Skeate, E.R.; Perrow, M.R.; Tomlinson, M.L.; Madgwick, G.; Harwood, A.J.P.; Ottewell, D.; Berridge, R.; Winfield, I.J. Fish stocking for recreational angling is culpable for the poor condition of many English lakes designated for conservation purposes. Inland Waters 2021, 1-14. [CrossRef]

16. Carpenter, S.R.; Kitchell, J.F.; Hodgson, J.R.; Cochran, P.A.; Elser, J.J.; Elser, M.M.; Lodge, D.M.; Kretchmer, D.; He, X.; von Ende, C.N. Regulation of lake primary productivity by food web structure. Ecology 1987, 68, 1863-1876. [CrossRef]

17. Vanni, M.J. Nutrient cycling by animals in freshwater ecosystems. Annu. Rev. Ecol. Syst. 2002, 33, 341-370. [CrossRef]

18. Vanni, M.J. Nutrient transport and recycling by consumers in lake food webs: Implications for algal communities. Food Webs 1996, 81-95. [CrossRef]

19. Scheffer, M.; Portielje, R.; Zambrano, L. Fish facilitate wave resuspension of sediment. Limnol. Oceanogr. 2003, 48, 1920-1926. [CrossRef]

20. Zhang, X.; Mei, X.; Gulati, R.D. Effects of omnivorous tilapia on water turbidity and primary production dynamics in shallow lakes: Implications for ecosystem management. Rev. Fish. Biol. Fish. 2017, 27, 245-254. [CrossRef]

21. Breukelaar, A.W.; Lammens, E.H.R.R.; Breteler, J.G.P.K.; Tátrai, I. Effects of benthivorous bream (Abramis brama) and carp (Cyprinus carpio) on sediment resuspension and concentrations of nutrients and chlorophyll a. Freshw. Biol. 1994, 32, 113-121. [CrossRef]

22. Stein, R.A.; DeVries, D.R.; Dettmers, J.M. Food-web regulation by a planktivore: Exploring the generality of the trophic cascade hypothesis. Can. J. Fish. Aquat. Sci. 1995, 52, 2518-2526. [CrossRef]

23. Dettmers, J.M.; Stein, R.A. Quantifying linkages among gizzard shad, zooplankton, and phytoplankton in reservoirs. Transac. Am. Fish. Soc. 1995, 125, 27-41. [CrossRef]

24. Jeppesen, E.; Jensen, J.P.; Søndergaard, M.; Lauridsen, T. Trophic dynamics in turbid and clearwater lakes with special emphasis on the role of zooplankton for water clarity. Hydrobiologia 1999, 408, 217-231. [CrossRef] 
25. Richardson, M.J.; Whoriskey, F.G.; Roy, H. Turbidity generation and biological impacts of an exotic Carassius auratus, introduced into shallow seasonally anoxic pounds. J. Fish Biol. 1995, 47, 576-585.

26. Qiu, X.; Mei, X.; Razlutskij, V.; Rudstam, L.G.; Liu, Z.; Tong, C.; Zhang, X. Effects of common carp (Cyprinus carpio) on water quality in aquatic ecosystems dominated by submerged plants: A mesocosm study. Knowl. Manag. Aquat. Ecosyst. 2019, 420, 28. [CrossRef]

27. Huang, Y.; Mei, X.; Rudstam, L.G.; Taylor, W.D.; Urabe, J.; Jeppesen, E.; Liu, Z.; Zhang, X. Effects of crucian carp (Carassius auratus) on water quality in aquatic ecosystems: An experimental mesocosm study. Water 2020, 12, 14-44. [CrossRef]

28. Badiou, P.H.J.; Goldsborough, L.G. Ecological impacts of an exotic benthivorous fish, the common carp (Cyprinus carpio L.), on water quality, sedimentation, and submerged macrophyte biomass in wetland mesocosms. Hydrobiologia 2015, 755, 107-121. [CrossRef]

29. Gabaldóna, C.; Buseva, Z.; Illyovác, M.; Seda, J. Littoral vegetation improves the productivity of drainable fish ponds: Interactive effects of refuge for Daphnia individuals and resting eggs. Aquaculture 2018, 485, 111-118. [CrossRef]

30. Roberts, J.; Chick, A.; Oswald, L.; Thompson, P. Effect of carp, Cyprinus carpio L., an exotic benthivorous fish, on aquatic plants and water quality in experimental ponds. Mar. Freshw. Res. 1995, 46, 1171-1180. [CrossRef]

31. Stephen, D.; Balayla, D.M.; Bécares, E.; Collings, S.E.; Fernández-Aaláez, C.; Fernández-Aláez, M.; Ferriol, C.; García, P.; Gomá, J.; Gyllström, M.; et al. Continental-scale patterns of nutrient and fish effects on shallow lakes: Introduction to a pan-European mesocosm experiment. Freshw. Biol. 2004, 49, 1517-1524. [CrossRef]

32. Nico, L.; Schofield, P.J. Carassius auratus; USGS Non-indigenous Aquatic Species Database: Gainesville, FL, USA, 2006.

33. Abramenko, M.I.; Kravchenko, O.V.; Velikoivanenko, A.E. Population genetic structure of the goldfish Carassius auratus gibelio diploid-triploid complex from the Don River Basin. J. Ichthyol. 1997, 37, 56-65.

34. Xie, J.; Wen, J.; Chen, B.; Gui, J.F. Differential gene expression in fully-grown oocytes between gynogenetic and gonochoristic crucian carp. Gene 2001, 272, 109-116. [CrossRef]

35. Kuznetsov, V.A. Changes in the population structure and biological indices of the goldfish Carassius auratus gibelio in the Volga Stretch of the Kuibyshev Reservoir under conditions of intense anthropogenic load on the ecosystem. J. Ichthyol. 2004, 44, 167-174.

36. Spotila, J.R.; Terpin, K.M.; Koons, R.R.; Bonati, R.L. Temperature requirements of fishes from eastern Lake Erie and upper Niagara River. Environ. Biol. Fishes 1979, 4, 281-307. [CrossRef]

37. Pinder, A.C. Keys to the Freshwater Fish of Britain and Ireland, with Notes on Their Distribution and Ecology; Freshwater Biological Association: Ambleside, UK, 2003; 248p.

38. Rylková, K.; Kalous, L.; Bohlen, J.; Lamatsch, D.K.; Petrtý, M. Phylogeny and biogeographic history of the cyprinid fish genus Carassius (Teleostei: Cyprinidae) with focus on natural and anthropogenic arrivals in Europe. Aquaculture 2013, 380-383, 13-20. [CrossRef]

39. Grichik, V.V.; Burko, L.D. Animal World of Belarus. Vertebrate: A Tutorial; BSU: Minsk, Belarus, 2013; 399p.

40. Semenchenko, V.P.; Rizevsky, V.K.; Mastitsky, S.E.; Vezhnovets, V.V.; Pluta, M.V.; Razlutsky, V.I.; Laenko, T. Checklist of aquatic alien species established in large river basins of Belarus. Aquat. Invas. 2009, 4, 311-320. [CrossRef]

41. Barbour, M.T.; Gerritsen, J.; Snyder, B.D.; Stribling, J.B. Rapid Bioassessment Protocols for Use in Streams and Wadeable Rivers: Periphyton, Benthic Macroinvertebrates and Fish; USEPA: Washington, DC, USA, 1999; 337p.

42. Jespersen, A.M.; Christoffersen, K. Measurements of chlorophyll a from phytoplankton using ethanol as extraction solvent. Arch. Hydrobiol. 1987, 109, 445-454.

43. Kutikova, L.A. Rotatoria of the Fauna of the USSR; Leningrad: Leningrad, Russia, 1970; 744p.

44. Błedzki, L.A.; Rybak, J.I. Cladocera Morphology. In Freshwater Crustacean Zooplankton of Europe; Springer: Berlin/Heidelberg, Germany, 2016; pp. 95-101.

45. Kaya, M.; Erdoğan, S. Morphological examination of the resting egg structure of 3 cladoceran species [Ceriodaphnia quadrangula (O. F. Müller, 1785), Daphnia longispina (O. F. Müller, 1776), and D. magna Straus, 1820]. Turk. J. Zool. 2014, 38, 131-135. [CrossRef]

46. Vandekerkhove, J.; Declerck, S.; Vanhove, M.; Brendonck, L.; Jeppesen, E.; Conde Porcuna, J.M.; de Meester, L. Use of ephippial morphology to assess richness of anomopods: Potentials and pitfalls. J. Limnol. 2004, 63, 131-135. [CrossRef]

47. Vanni, M.J.; Boros, G.; Mcintyre, P.B. When are fish sources vs. sinks of nutrients in lake ecosystems? Ecology 2013, 94, $2195-2206$. [CrossRef]

48. Guo, X.T.; Liu, F.; Wang, F. Carbon, nitrogen, and phosphorus stoichiometry of three freshwater cultured fishes in growth stage. Turk. J. Fish Aquat. Sci. 2018, 18, 239-245. [CrossRef]

49. Rhee, G.Y. Competition between an alga and an aquatic bacterium for phosphate. Limnol. Oceanogr. 1972, 17, 505-514. [CrossRef]

50. Grover, J.P. Resource competition and community structure in aquatic microorganisms: Experimental studies of algae and bacteria along a gradient of organic carbon to inorganic phosphorus supply. J. Plankton Res. 2000, 22, 1591-1610. [CrossRef]

51. Danger, M.; Oumarou, C.; Benest, D.; Lacroix, G.G. Bacteria can control stoichiometry and nutrient limitation of phytoplankton. Funct. Ecol. 2007, 21, 202-210. [CrossRef]

52. Schwaderer, A.; Yoshiyama, K.; de Tezanos Pinto, P.; Swenson, N.G.; Christopher, A.; Klausmeier, C.A.; Litchman, E. Ecoevolutionary differences in light utilization traits and distributions of freshwater phytoplankton. Limnol. Oceanogr. 2011, 56, 589-598. [CrossRef]

53. Van Donk, E.; van de Bund, W.J. Impact of submerged macrophytes including charophytes on phyto-and zooplankton communities: Allelopathy versus other mechanisms. Aquat. Bot. 2002, 72, 261-274. [CrossRef] 
54. Rybak, A.S.; Gabka, M. The influence of abiotic factors on the bloom-forming alga Ulva flexuosa (Ulvaceae, Chlorophyta): Possibilities for the control of the green tides in freshwater ecosystems. J. Appl. Phycol. 2018, 30, 1405-1416. [CrossRef]

55. Erhard, D.; Gross, E.M. Allelopathic activity of Elodea canadensis and Elodea nuttallii against epiphytes and phytoplankton. Aquat. Bot. 2006, 85, 203-211. [CrossRef]

56. Pakdel, F.M.; Sim, L.; Beardall, J.; Davis, J. Allelopathic inhibition of microalgae by the freshwater stonewort, Chara australis, and a submerged angiosperm, Potamogeton crispus. Aquat. Bot. 2013, 110, 24-30. [CrossRef]

57. Ibelings, B.W.; Portielje, R.; Lammens, E.H.R.R.; Noordhuis, R.; van den Berg, M.; Willemien, J.; Meijer, M.L. Resilience of alternative stable states during the recovery of shallow lakes from eutrophication: Lake Veluwe as a case study. Ecosystems 2007, 10, 4-16. [CrossRef]

58. De Winton, M.D.; Taumoepeau, A.T.; Clayton, J.S. Fish effects on charophyte establishment in a shallow, eutrophic New Zealand lake. N. Z. J. Mar. Freshw. Res. 2002, 36, 815-823. [CrossRef]

59. Blindow, I. Decline of charophytes during eutrophication: Comparison with angiosperms. Freshw. Biol. 1992, 28, 9-14. [CrossRef]

60. Liboriussen, L.; Jeppesen, E. Temporal dynamics in epipelic, pelagic and epiphytic algal production in a clear and turbid shallow lake. Freshw. Biol. 2003, 48, 418-431. [CrossRef]

61. Barko, J.W.; James, W.F. Effects of Submerged Aquatic Macrophytes on Nutrient Dynamics, Sedimentation, Resuspension; Jeppesen, E., Søndergaard, M., Christoffersen, K., Eds.; Springer: New York, NY, USA, 1998; pp. 197-214.

62. Carlton, R.G.; Wetzel, R.G. Phosphorus flux from lake sediments: Effects of epipelic algal oxygen production. Limnol. Oceanogr. 1988, 33, 562-570. [CrossRef]

63. Brooks, J.; Dodson, S. Predation, body size and composition of plankton. Science 1965, 150, 28-35. [CrossRef]

64. Mellors, W.K. Selective predation of ephippal daphnia and the resistance of ephippal eggs to digestion. Ecology 1975, 56, 974-980. [CrossRef] 